\title{
Temporal changes in allele frequencies but stable genetic diversity over the past 40 years in the Irish Sea population of thornback ray, Raja clavata
}

\author{
M Chevolot ${ }^{1,4}$, JR Ellis ${ }^{2}$, AD Rijnsdorp ${ }^{3}$, WT Stam ${ }^{1}$ and JL Olsen ${ }^{1}$ \\ ${ }^{1}$ Department of Marine Benthic Ecology and Evolution, Centre for Ecological and Evolutionary Studies, Biological Centre, University \\ of Groningen, Haren, The Netherlands; ${ }^{2}$ Centre for Environment, Fisheries and Aquaculture Science, Lowestoft Laboratory, Lowestoft, \\ Suffolk, UK and ${ }^{3}$ Wageningen Institute for Marine Resources and Ecological Studies (IMARES), Animal Sciences Group, Wageningen \\ UR, IJmuiden, The Netherlands
}

\begin{abstract}
Rays and skates are an unavoidable part of the by-catch in demersal fisheries. Over the past 40 years, the thornback ray (Raja clavata) has decreased in numbers and even disappeared in some areas, leading to concerns about genetic risk. For this reason, the effective population size $\left(N_{\mathrm{e}}\right)$, the migration rate $(m)$ and temporal changes in the genetic diversity were estimated for the population of thornback rays in the Irish Sea and Bristol Channel. Using genotyped, archived and contemporary samples (1965 and 2003-2004), $N_{e}$ was estimated at 283 individuals $(95 \%$ $\mathrm{Cl}=145-857), m$ at $0.1(95 \% \mathrm{Cl}=0.03-0.25)$ and the $N_{\mathrm{e}} / N$ ratio between $9 \times 10^{-5}$ and $6 \times 10^{-4}$. Although these results must be treated with caution, due to the small sample sizes, this is the first attempt to estimate $N_{e}$ in an elasmobranch
\end{abstract}

species. The low $N_{\mathrm{e}} / N$ ratio suggests that relatively few individuals contribute to the next generation. The combined effect of sex bias, inbreeding, fluctuations in population size and, perhaps most important, the variance in reproductive success may explain the low $N_{\mathrm{e}} / N$ ratio. In addition, the relatively high gene flow between Irish Sea population and other source populations is likely to have had an impact on our estimate, which may be more relevant at the metapopulation scale. No significant loss of genetic diversity was found over the 40-year timeframe and long-term maintenance of the genetic diversity could be due to gene flow.

Heredity (2008) 101, 120-126; doi:10.1038/hdy.2008.36; published online 7 May 2008

Keywords: effective population size; census population size; genetic diversity; elasmobranchs; thornback ray; Raja clavata

\section{Introduction}

Preventing loss of genetic diversity is one of the priorities for conservation and has long been acknowledged to be important for the evolutionary potential of a species (Frankham, 1995; Franklin and Frankham, 1998). In an isolated population, the level of genetic diversity is the result of equilibrium between mutations, which generate genetic variation; and genetic drift, which decreases it. In small populations, the probabilities of losing rare alleles and increasing the frequency of deleterious alleles are higher as the effect of genetic drift is stronger (Lande, 1995; Franklin and Frankham, 1998). This can reduce population fitness and increase the risk of population extinction. Genetic diversity is coupled with the effective population size $\left(N_{\mathrm{e}}\right)$, which refers to the size of an ideal population with the same rate of genetic drift as the studied population (Wright, 1931). In a review of 192 studies, Frankham (1995) established that, on average, $N_{\mathrm{e}}$ is nine times smaller than the census population size $(N)$. In marine teleosts this ratio can be much smaller,

Correspondence: Dr M Chevolot, UMR 547-PIAF, INRA/Université Blaise Pascal, 24 avenue des landais, Aubière, Cedex 63177, France.

E-mail: malia.chevolot@univ-bpclermont.fr

${ }^{4}$ Current address: UMR 547-PIAF, INRA/Université Blaise Pascal, Aubière, Cedex, France

Received 5 June 2007; revised 18 March 2008; accepted 21 March 2008; published online 7 May 2008 generally estimated at about $10^{-5}$ (Hauser et al., 2002; Hutchinson et al., 2003; Hoarau et al., 2005; Poulsen et al., 2006), though Turner et al. (2002) estimated $10^{-3}$ in red drum Sciaenops ocellatus. Hence, $N_{\mathrm{e}}$ is an important parameter in population risk assessment.

Direct estimates of $N_{\mathrm{e}}$ are difficult unless good estimates of the mating system and long-term population demography are known. An alternative indirect approach for estimating $N_{\mathrm{e}}$ is to examine temporal changes in allelic frequencies, under the assumption that they are explained by genetic drift (that is, by assuming the effects of mutation, migration and selection are negligible, or by allowing for them; Waples, 1989; Wang and Whitlock, 2003; Wang, 2005). This temporal method has been found to be more reliable than estimates based on demographic data (Frankham et al., 2002).

Skates (Rajidae) are particularly vulnerable to exploitation because of their life history traits: slow growth rate, late maturity, low fecundity and large size at hatching (Heist, 1999; Dulvy et al., 2000). Female thornback rays, Raja clavata L., mature between 9 and 12 years of age (Nottage and Perkins, 1983) and produce 38-150 eggs per female per year (Holden, 1975; Ryland and Ajayi, 1984; Ellis and Shackley, 1995; Chevolot et al., 2007).

Many skate species are taken as by-catch in mixed demersal fisheries, and some are also taken in directed fisheries and recreational fisheries. Unfortunately, 
long-term data on landings are not available on a speciesspecific basis (Dulvy et al., 2000; Ellis et al., 2005), so that even the disappearance of the common skate Dipturus batis (Brander, 1981; (Dulvy et al., 2000) or the decline of the white skate (Rostroraja alba) Dulvy et al., 2000) went relatively unnoticed. Thornback rays are targeted in inshore longline and gillnet fisheries in coastal waters of the British Isles, and are also an important component of the mixed demersal trawl fisheries. Despite being one of the most commercially valuable rays, the economic value of their total catch is small in comparison to other demersal species (for example, sole and plaice), consequently skates have not been the focus of fisheries management. They are now a high priority for assessment because they are thought to have declined by about $45 \%$ in the Irish Sea (Dulvy et al., 2000; Rogers and Ellis, 2000) and nearly $80 \%$ in the North Sea (Walker and Heessen, 1996). Although thornback ray is locally abundant in the south-western North Sea, its decline in other parts of the North Sea has prompted further concern about its sustainability (Walker and Heessen, 1996; ICES, 2007), and ICES (ICES, 2006) advised a zero quota for North Sea skates and rays if they continue to be managed under a common TAC (total allowable catch). For all of these reasons, skates and elasmobranchs in general are now a high priority for stock assessment (Heessen, 2004; Ellis et al., 2005).

In the North Sea, tagging studies indicated that most individuals forage within 20 nautical miles (nmi; Walker et al., 1997). This 'home range' has since been extended to a maximum travelling distance of $70 \mathrm{nmi}$ from studies using data storage tags (Hunter et al., 2005). In the Irish Sea and Bristol Channel, tagging studies showed that few individuals were recaptured from outside the Irish Sea/Bristol Channel area (Cefas, unpublished data). These results suggested that $R$. clavata populations are moderately isolated.

The aims of this study were to estimate whether there has been a loss in genetic diversity in $R$. clavata in the Irish Sea/Bristol Channel over the past 40 years, and to estimate $N_{\mathrm{e}}$, the effective population size, by comparing archived vertebrae collected in 1965 with contemporary samples collected in 2003-2004.

\section{Materials and methods}

\section{Sampling}

Archived samples of vertebrae collected in 1965 from the Irish Sea were obtained from the CEFAS (Centre for Environment, Fisheries and Aquaculture Science) archives in Lowestoft, UK (Figure 1; Table 1). Contemporary samples were collected in 2003 and 2004 and were part of a previous study on $R$. clavata (Chevolot et al., 2006). From this previous study, five locations sampled in the Irish Sea/Bristol Channel were reanalysed (Figure 1; Table 1), as well as five other locations sampled in the North Sea and English Channel.

\section{DNA extraction and genotyping}

Archived vertebrae were preserved in ethanol, and DNA was extracted using a specialized SDS-based protocol (Hutchinson et al., 1999). All extractions of archived samples were performed in a DNA-free laboratory using filter tips for pipettes to avoid contamination and with

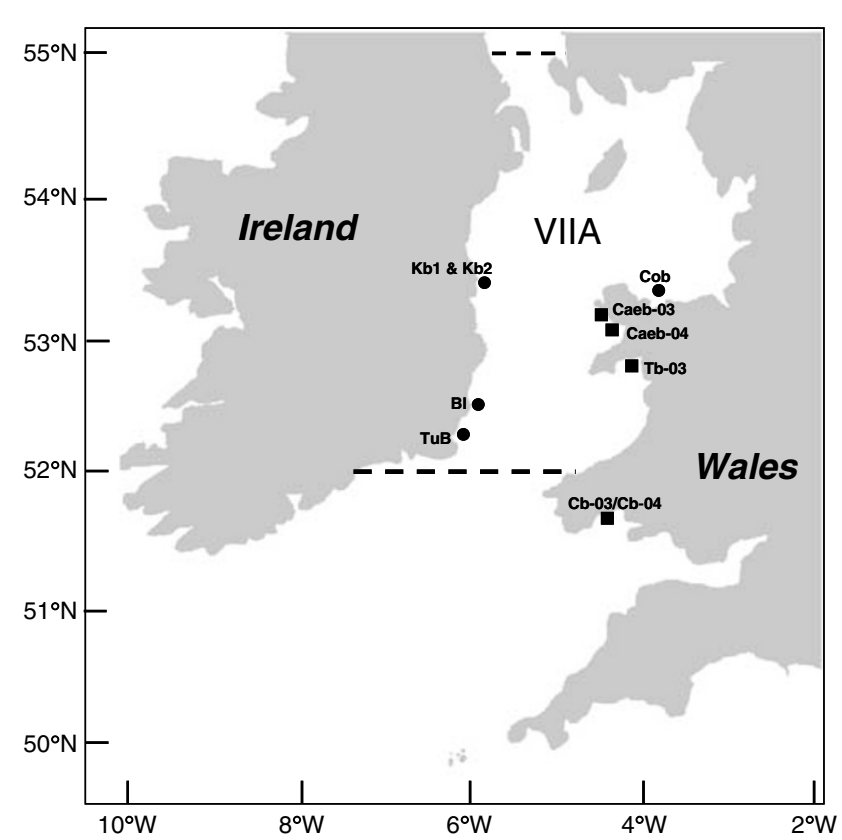

Figure 1 Sampling locations of Raja clavata. Black dashed lines delimit the sampling location named VIIA (see Table 1), which corresponds to the VIIa ICES rectangle. Circles denote 1965 samples; squares, 2003-2004 samples. Putative source populations are not shown. For the complete sampling map see Chevolot et al. (2006).

Table 1 Sampling information for Raja clavata

\begin{tabular}{|c|c|c|c|c|c|}
\hline Location & Code & $\mathrm{N}$ & $\begin{array}{l}\text { Life } \\
\text { stage }\end{array}$ & Tissue & $\begin{array}{l}\text { Sampling } \\
\text { date }\end{array}$ \\
\hline $\begin{array}{l}\text { Blackwater } \\
\text { Bay }\end{array}$ & $\mathrm{Bl}$ & 23 & Adults & Vertebrae & May 1965 \\
\hline Conwy Bay & $\mathrm{CoB}$ & 10 & Adults & Vertebrae & October 1965 \\
\hline Kish Bank 1 & $\mathrm{~Kb} 1$ & 24 & Adults & Vertebrae & October 1965 \\
\hline Kish Bank 2 & $\mathrm{~Kb} 2$ & 20 & Adults & Vertebrae & July 1965 \\
\hline $\begin{array}{l}\text { Tuskaw } \\
\text { Bay }\end{array}$ & $\mathrm{TuB}$ & 26 & Adults & Vertebrae & May 1965 \\
\hline $\begin{array}{l}\text { ICES area } \\
\text { VIIA }\end{array}$ & VIIA & 45 & Adults & Vertebrae & July 1965 \\
\hline $\begin{array}{l}\text { Carmarthen } \\
\text { Bay } 03\end{array}$ & $\mathrm{Cb}-03$ & 16 & Juveniles & Muscle & September 2003 \\
\hline $\begin{array}{l}\text { Carmarthen } \\
\text { Bay } 04\end{array}$ & $\mathrm{Cb}-04$ & 33 & Juveniles & Muscle & September 2004 \\
\hline $\begin{array}{l}\text { Caernarfon } \\
\text { Bay } 03\end{array}$ & Caeb-03 & 18 & Juveniles & Muscle & September 2003 \\
\hline $\begin{array}{l}\text { Caernarfon } \\
\text { Bay } 04\end{array}$ & Caeb-04 & 16 & Juveniles & Muscle & November 2004 \\
\hline $\begin{array}{l}\text { Tremadog } \\
\text { Bay } 03\end{array}$ & $\mathrm{~Tb}-03$ & 18 & Juveniles & Muscle & September 2003 \\
\hline $\begin{array}{l}\text { Thames } \\
\text { estuary } 1\end{array}$ & Te1-03 & 35 & Juveniles & Muscle & February 2003 \\
\hline $\begin{array}{l}\text { Thames } \\
\text { estuary } 2\end{array}$ & Te2-04 & 21 & Juveniles & Muscle & August 2004 \\
\hline $\begin{array}{l}\text { English } \\
\text { Channel } 2\end{array}$ & Ec2-02 & 19 & Juveniles & Muscle & April 2002 \\
\hline Lyme Bay & LyB-03 & 18 & Juveniles & Muscle & September 2003 \\
\hline $\begin{array}{l}\text { East English } \\
\text { Channel }\end{array}$ & Eec-04 & 21 & Juveniles & Muscle & September 2003 \\
\hline
\end{tabular}

negative controls at all steps. Contemporary samples (muscle tissue) were extracted using a silica-based protocol (Elphinstone et al., 2003).

Samples were genotyped for five unlinked microsatellite loci as described in Chevolot et al. (2005). PCR products were separated on a $6 \%$ polyacrylamide gel and 
visualized with an ABI Prism-377 automatic sequencer (Applied Biosystems). Allele size was determined using an internal lane standard (GENESCAN 350 Rox) and GENESCAN software (Applied Biosystems).

\section{Data analysis}

The software MICRO-CHECKER 2.2.1 (Van Oosterhout et al., 2004) was used to check for null alleles, stuttering and large allele drop out. For all samples, GENETIX 4.05 software (Belkhir et al., 2004) was used to estimate the following: (1) the unbiased expected heterozygosity $\left(H_{\text {exp }}\right)$ (Nei, 1978) and observed heterozygosity $\left(H_{\mathrm{obs}}\right)$; (2) the number of alleles $\left(N_{\mathrm{a}}\right)$ for each locus and location; (3) the single and multilocus $F_{\text {IS }}$ estimate using Weir and Cockerham $f$ estimator and (4) global and pairwise $F_{\mathrm{ST}}$ to test for population differentiation using Weir and Cockerham $\theta$ estimator (Weir and Cockerham, 1984). Significance was tested against 10000 permutations and corrected using the sequential Bonferroni method when necessary (Rice, 1989).
The effective population size, $N_{\mathrm{e}}$, was estimated alone and jointly with the migration rate, $m$. In both cases, we used a pseudo-likelihood method implemented in the software MLNE 2.0 (Wang and Whitlock, 2003). The idea is to estimate the $N_{\mathrm{e}}$ based on the fluctuations in allelic frequencies between at least two temporal samples separated by a known number of generations (Waples, 1989; Wang and Whitlock, 2003). When $N_{\mathrm{e}}$ is estimated alone, it is assumed that the population is isolated. When $N_{\mathrm{e}}$ and $m$ are jointly estimated, the assumption is that migrants are coming from an infinitely large source population and migration rate is constant. However, the method to estimate $N_{\mathrm{e}}$ and $m$ jointly is robust to deviations from the assumption of an infinitely large source population (Wang and Whitlock, 2003). Our definition of the source population was based on results from a previous study in Chevolot et al. (2006). Locations Te1-03, Te2-04, Ec2-02, LyB-03, Eec-04 (see Figure 1 in Chevolot et al., 2006), which showed no significant differentiation with contemporary samples from the Irish Sea and Bristol Channel (Cb-03, Cb-04, CaeB-03, CaeB-04,

Table 2 Summary statistics of genetic variability for five microsatellite loci for locations sampled for Raja clavata

\begin{tabular}{|c|c|c|c|c|c|c|c|c|c|c|c|c|}
\hline \multirow[b]{2}{*}{ Locus } & \multicolumn{12}{|c|}{ Location } \\
\hline & $B l$ & $\mathrm{Cob}$ & $K b 1$ & $K b 2$ & $\mathrm{Tu} B$ & VIIA & $\mathrm{Cb}-03$ & $\mathrm{Cb}-04$ & Caeb-03 & Caeb-04 & $\mathrm{Tb}-03$ & $\begin{array}{l}\text { Mean } N_{a} \\
\text { per locus }\end{array}$ \\
\hline \multicolumn{13}{|l|}{ Rc-B3 } \\
\hline$N$ & 20 & 8 & 17 & 22 & 24 & 43 & 14 & 22 & 17 & 12 & 15 & \\
\hline$N_{\mathrm{a}}$ & 6 & 4 & 3 & 4 & 5 & 7 & 5 & 5 & 4 & 3 & 5 & 4.6 \\
\hline$H_{\text {exp }}$ & 0.66 & 0.711 & 0.642 & 0.744 & 0.661 & 0.761 & 0.622 & 0.584 & 0.635 & 0.632 & 0.595 & \\
\hline$H_{\text {obs }}$ & 0.435 & 0.800 & 0.632 & 0.792 & 0.600 & 0.533 & 0.429 & 0.438 & 0.556 & 0.600 & 0.530 & \\
\hline$f$ & $0.320^{*}$ & -0.076 & 0.017 & -0.050 & $0.382^{*}$ & $0.335^{*}$ & -0.014 & $0.356^{*}$ & 0.106 & -0.029 & 0.141 & \\
\hline \multicolumn{13}{|l|}{ Rc-B4 } \\
\hline$N$ & 20 & 8 & 17 & 22 & 24 & 43 & 14 & 22 & 17 & 12 & 15 & \\
\hline$N_{\mathrm{a}}$ & 17 & 11 & 15 & 19 & 20 & 22 & 14 & 22 & 20 & 15 & 17 & 17.5 \\
\hline$H_{\exp }$ & 0.936 & 0.942 & 0.928 & 0.941 & 0.937 & 0.946 & 0.938 & 0.9531 & 0.962 & 0.934 & 0.951 & \\
\hline$H_{\mathrm{obs}}$ & 0.909 & 0.900 & 1.000 & 1.000 & 0.885 & 0.932 & 0.875 & 0.933 & 0.944 & 0.938 & 0.833 & \\
\hline$f$ & -0.011 & 0.08 & -0.08 & -0.057 & 0.065 & 0.016 & 0.009 & 0.043 & 0.023 & -0.004 & $0.092^{*}$ & \\
\hline \multicolumn{13}{|l|}{ Rc-B6 } \\
\hline$N$ & 20 & 8 & 17 & 22 & 24 & 43 & 14 & 22 & 17 & 12 & 15 & \\
\hline$N_{\mathrm{a}}$ & 18 & 11 & 18 & 16 & 24 & 25 & 21 & 21 & 21 & 16 & 18 & 19 \\
\hline$H_{\text {exp }}$ & 0.943 & 0.942 & 0.935 & 0.896 & 0.937 & 0.937 & 0.938 & 0.899 & 0.925 & 0.899 & 0.95 & \\
\hline$H_{\text {obs }}$ & 0.955 & 1.000 & 0.790 & 0.957 & 0.923 & 1.000 & 0.938 & 0.9394 & 1.000 & 0.938 & 1.000 & \\
\hline$f$ & -0.011 & -0.066 & $0.131^{*}$ & -0.059 & -0.016 & -0.066 & 0.003 & -0.091 & -0.075 & -0.109 & -0.047 & \\
\hline \multicolumn{13}{|l|}{ Rc-G2 } \\
\hline$N$ & 20 & 8 & 17 & 22 & 24 & 43 & 14 & 22 & 17 & 12 & 15 & \\
\hline$N_{\mathrm{a}}$ & 5 & 5 & 6 & 5 & 4 & 7 & 4 & 5 & 5 & 3 & 6 & 5 \\
\hline$H_{\text {exp }}$ & 0.585 & 0.511 & 0.612 & 0.667 & 0.580 & 0.584 & 0.635 & 0.637 & 0.674 & 0.394 & 0.544 & \\
\hline$H_{\mathrm{obs}}$ & 0.565 & 0.400 & 0.550 & 0.708 & 0.560 & 0.556 & 0.625 & 0.540 & 0.647 & 0.462 & 0.625 & \\
\hline$f$ & 0.034 & $0.451^{*}$ & 0.010 & -0.072 & 0.029 & 0.075 & 0.091 & 0.146 & 0.041 & -0.118 & -0.125 & \\
\hline \multicolumn{13}{|l|}{ Rc-E9 } \\
\hline$N$ & 20 & 8 & 17 & 22 & 24 & 43 & 14 & 22 & 17 & 12 & 15 & \\
\hline$N_{\mathrm{a}}$ & 4 & 3 & 6 & 4 & 7 & 5 & 3 & 6 & 3 & 5 & 6 & 4.7 \\
\hline$H_{\exp }$ & 0.392 & 0.451 & 0.293 & 0.576 & 0.499 & 0.448 & 0.502 & 0.617 & 0.418 & 0.587 & 0.638 & \\
\hline $\begin{array}{l}H_{\text {obs }} \\
\text { exp }\end{array}$ & 0.364 & 0.444 & 0.263 & 0.522 & 0.520 & 0.422 & 0.438 & 0.606 & 0.389 & 0.625 & 0.833 & \\
\hline$f^{\text {obs }}$ & 0.059 & 0.125 & 0.096 & 0.000 & -0.029 & 0.073 & 0.197 & -0.039 & 0.059 & -0.146 & -0.254 & \\
\hline Mean $N_{\mathrm{a}}$ & 10 & 7 & 9.6 & 9.6 & 12,0 & 13,2 & 8.8 & 11.8 & 10.4 & 8.4 & 10.4 & \\
\hline Multilocus $H_{\exp }$ & 0.703 & 0.711 & 0.682 & 0.765 & 0.723 & 0.735 & 0.726 & 0.738 & 0.723 & 0.689 & 0.735 & \\
\hline Multilocus $f$ & 0.084 & 0.003 & 0.050 & -0.042 & 0.090 & 0.064 & 0.09 & 0.030 & 0.020 & -0.030 & -0.040 & \\
\hline
\end{tabular}

$N$ is number of individuals; $N_{\mathrm{a}}$, number of alleles; $H_{\text {exp }}$, non-biased expected heterozygosity; $H_{\mathrm{obs}}$, observed heterozygosity; $f$, inbreeding coefficient (Weir and Cockerham, 1984).

Significant values are in bold after Bonferroni corrections (* denotes $P<0.05$ ). 
$\mathrm{Tb}-03)$ were pooled to form the source population. Based on an estimated generation time of 10 years for $R$. clavata (Maxwell and Jennings, 2005), it was assumed that four generations separated the two temporal samples.

To compare genetic diversity between archived and contemporary samples and to test for loss of genetic diversity, we estimated the allelic richness for each temporal sample using the mean number of alleles per locus $\left(N_{\mathrm{a}}\right)$ and the unbiased expected heterozygosity, $H_{\text {exp }}$ (Nei, 1978). As the number of alleles and the expected heterozygosity are strongly dependent on sample size, GENCLONE (Arnaud-Haond and Belkhir, 2007) was used to correct for uneven sample sizes with a resampling procedure. Mean allelic diversity and the non-biased expected heterozygosity were calculated across all resampling procedures. The allelic diversity was estimated with 1000 resampling procedures and corrected for the smallest sample size. Differences in allelic richness and expected heterozygosity between archived and contemporary samples were tested using a Wilcox rank sum test (Wilcoxon, 1945).

\section{Results}

\section{Data quality}

Evidence for null alleles was found in only one locus, Rc-B3 at VIIA, TuB and Bl locations collected in 1965. For the other microsatellite loci and sampling locations, no evidence for null alleles, stuttering and large allele drop out was observed. Deviations from Hardy-Weinberg equilibrium were observed for the locus Rc-B3 at VIIA, $\mathrm{TuB}, \mathrm{Bl}$ and $\mathrm{Cb}-04$ locations; for Rc-B4 at Tb location; for Rc-B6 at Kb1 location and Rc-G2 at Cob location. For all locations, the multilocus $f$ was not significant after Bonferroni corrections $(P>0.05)$ (Table 2).

\section{Population differentiation}

The global genetic differentiation among locations sampled in 1965 was extremely low $(\theta=0.004)$ and not significant $(P=0.1)$. Removal of locus Rc-B3 from the analysis (which has significant null alleles) did not affect the results. Similarly, no significant genetic differentiation between 2003-2004 samples was observed $(\theta=0.005$; $P=0.15)$. Without Bonferroni corrections, pairwise multilocus $\theta$ estimates among the 11 locations showed that location $\mathrm{Kb} 2$ was significantly different from 7 locations; 2 of them being historical sampling sites. Kb1 was significantly differentiated from 4 locations; three were contemporary sampling sites (Table 3). Following Bonferroni corrections, none of the pairwise comparisons remained significant. Thus, samples from 1965 were pooled (excluding $\mathrm{Kb} 2$ ) into a single population. All 2003-2004 samples were pooled into a single population. Genetic differentiation between the two temporal samples was low $(\theta=0.007)$ but in this case highly significant $(P<0.001)$.

\section{Estimation of effective population size}

The joint estimation of $N_{\mathrm{e}}$ and $m$ by the pseudomaximum likelihood method, based on five loci, was 283 individuals (95\% $\mathrm{CI}=145-857)$ and $0.1 \quad(95 \%$ $\mathrm{CI}=0.03-0.25)$, respectively. The estimation of $N_{\mathrm{e}}$ alone gave an estimation of $512(95 \% \mathrm{CI}=259-2320)$. Based on annual ground fish surveys, adult census population size in the Irish Sea and Bristol Channel (ICES Divisions VIIa, f) can be estimated to be in the order of 0.5-3 million mature individuals (JR Ellis, unpublished data). Thus, the $N_{\mathrm{e}} / N$ ratio ranges approximately between $9 \times 10^{-5}$ and $6 \times 10^{-4}$ (with migration), or $1.8 \times 10^{-4}$ and $10^{-3}$ (without migration).

\section{Temporal patterns in genetic diversity}

The number of alleles per locus varied from 7 (Rc-B3) to 45 (Rc-B6) among all locations in 1965 and from 6 (Rc-B3) to 41 (Rc-B6) in the contemporary samples (Table 3). Following correction for sample size with GENCLONE, mean expected heterozygosity was 0.733 and 0.719 for

Table 4 Comparison of the genetic diversity at five microsatellite loci in Raja clavata population sampled in 1965 and 2003-2004

\begin{tabular}{|c|c|c|c|c|c|c|c|c|}
\hline \multirow[t]{2}{*}{ Locus } & \multicolumn{5}{|c|}{1965} & \multicolumn{3}{|c|}{2004} \\
\hline & $\mathrm{N}_{a}$ & $\mathrm{H}_{o b s}$ & $\mathrm{H}_{\exp }$ & $\mathrm{N}_{c}$ & $\mathrm{H}_{\text {expc }}$ & $\mathrm{N}_{a}$ & $\mathrm{H}_{o b s}$ & $\mathrm{H}_{\exp }$ \\
\hline Rc-B3 & 7 & 0.523 & 0.708 & 6.81 & 0.711 & 6 & 0.541 & 0.601 \\
\hline Rc-B4 & 27 & 0.928 & 0.941 & 26.21 & 0.942 & 27 & 0.908 & 0.943 \\
\hline Rc-B6 & 45 & 0.955 & 0.943 & 42.47 & 0.947 & 41 & 0.960 & 0.927 \\
\hline Rc-G2 & 8 & 0.523 & 0.557 & 8.62 & 0.583 & 6 & 0.620 & 0.621 \\
\hline Rc-E9 & 8 & 0.414 & 0.435 & 8.41 & 0.461 & 8 & 0.528 & 0.520 \\
\hline Mean & 19 & 0.669 & 0.716 & 19.2 & 0.733 & 17.6 & 0.705 & 0.719 \\
\hline
\end{tabular}

$N_{\mathrm{a}}$ is number of alleles; $H_{\text {exp }}$ non-biased expected heterozygosity (Nei, 1978); $N_{\mathrm{c}}$ number of alleles corrected for sample size; $H_{\text {expc }}$ non-biased expected heterozygosity (Nei, 1978) corrected for sample size.

As contemporary population is the smallest, no correction for sample size was done (see Materials and methods).

Table 3 Pairwise $F_{\mathrm{ST}}$ comparisons among the 11 locations

\begin{tabular}{|c|c|c|c|c|c|c|c|c|c|c|c|}
\hline Locations & $B l$ & $\mathrm{Cob}$ & $K b 1$ & $K b 2$ & ТиB & VIIA & $\mathrm{Cb}-03$ & $\mathrm{Cb}-04$ & Caeb-03 & Caeb-04 & $T b-03$ \\
\hline $\mathrm{Bl}$ & - & -0.016 & 0.013 & $0.016^{*}$ & -0.004 & 0.001 & -0.003 & 0.011 & 0.005 & 0.002 & -0.011 \\
\hline Cob & & - & -0.008 & 0.014 & -0.015 & -0.012 & -0.009 & 0.001 & -0.002 & -0.010 & -0.020 \\
\hline $\mathrm{Kb} 1$ & & & - & $0.031^{*}$ & 0.002 & 0.010 & $0.029 *$ & $0.043^{* *}$ & $0.025^{*}$ & 0.012 & 0.002 \\
\hline $\mathrm{Kb} 2$ & & & & - & 0.009 & 0.002 & $0.022^{*}$ & $0.025^{* *}$ & $0.019^{*}$ & $0.017^{*}$ & $0.026^{*}$ \\
\hline TuB & & & & & - & -0.001 & 0.003 & 0.010 & 0.002 & -0.007 & -0.005 \\
\hline VIIA & & & & & & - & 0.006 & 0.018 & 0.006 & 0.004 & 0.004 \\
\hline $\mathrm{Cb}-03$ & & & & & & & - & & 0.001 & -0.000 & -0.007 \\
\hline $\mathrm{Cb}-04$ & & & & & & & & - & 0.011 & 0.012 & 0.006 \\
\hline Caeb-03 & & & & & & & & & - & 0.007 & 0.004 \\
\hline Caeb-04 & & & & & & & & & & - & 0.001 \\
\hline Tb-03 & & & & & & & & & & & - \\
\hline
\end{tabular}

Significant $P$-values are in bold, with ${ }^{*}$ when $P<0.05$ and ${ }^{*}$ when $P<0.01$. None of the pairwise comparisons remain significant after Bonferroni corrections (corrected $P=0.0009$ ). 
past and present samples, respectively (Table 4). The number of alleles per locus and expected heterozygosity were not significantly different $(P>0.20)$ between the two temporal samples, with or without Locus Rc-B3.

\section{Discussion}

\section{Effective population size}

The results presented here are the first attempt to estimate $N_{\mathrm{e}}$ and to follow genetic diversity through time in an elasmobranch. The estimated $N_{\mathrm{e}}$ for $R$. clavata is 283 (95\% CI $=145-857)$ when jointly estimated with $m$ and 512 when estimated alone $(95 \% \mathrm{CI}=259-2320)$. Simulation studies suggest that an $N_{\mathrm{e}}$ of 50 individuals represents the absolute minimum threshold below which genetic erosion will occur on the short term and that of 500 individuals represents the minimal threshold for long-term maintenance of the genetic diversity (Frankham, 1995; Franklin and Frankham, 1998). Although our estimated $N_{\mathrm{e}}$ is at the borderline, suggesting the need for a long-term monitoring of thornback rays, these results must be interpreted with caution due to the small sample size and number of markers.

\section{Factors influencing the estimate of $N_{\mathrm{e}}$}

Violations in underlying assumptions can affect the accuracy of the estimate of $N_{\mathrm{e}}\left(N_{\text {est }}\right)$. Cohort sampling effects and the underlying life history model (discrete generations) are some of these factors. In 1965, only adults were sampled, whereas in 2003-04 only juveniles were sampled. As age cohorts might be genetically differentiated, $N_{\text {est }}$ could, in principle, be underestimated. However, the results of Chevolot et al. (2006) suggested high migration rates among juveniles independent of length class. Secondly, the model used to estimate the effective population size assumes discrete generations. Waples and Yokota (2007) reported that particular caution should be taken when estimating $N_{\mathrm{e}}$ in species with overlapping generations. They found that estimation of $N_{\mathrm{e}}$ could be biased and the bias was dependent upon the type of survival curve of the species. $R$. clavata has a type II survivorship curve as mortality is assumed to be constant throughout the cohorts. Thus, $N_{\text {est }}$ is likely to have been underestimated (Waples and Yokota, 2007). To get a better $N_{\text {est }}$ for $R$. clavata, larger sample sizes and greater temporal separation would be desirable. However, as is the case for most species, including $R$. clavata, archived samples are rare and usually restricted to small areas and relatively short periods of time.

Gene flow can have an impact on $N_{\text {est }}$. The estimated migration rate found here is 0.1 migrant per generation. Although there are few records of skates tagged in the Irish Sea and Bristol Channel being recaptured from outside this area (Pawson and Nichols, 1994), this estimated $m$ supports the weak, though significant, genetic differentiation found in British waters (Chevolot et al., 2006). Therefore, the Irish Sea/Bristol Channel population is not completely isolated and the temporal changes are not only due to genetic drift but also due to gene flow. According to Wang and Whitlock (2003), the effect of gene flow should cause underestimation of $N_{\text {est }}$ in the short term, if migration is ignored. This is because the change in allele frequencies is larger than expected by genetic drift alone. However, as reported by Fraser et al. (2007), the bias on $N_{\text {est }}$ strongly depends on the extent of genetic differentiation between the source and the receiving populations. In cases where genetic differentiation between populations is low, as is the case here for thornback rays (global $\theta$ in British waters = 0.013; see Chevolot et al., 2006), $N_{\text {est }}$ could be overestimated if migration is ignored, as migration might counterbalance the effect of genetic drift. Here, $N_{\mathrm{e}}$ estimated with genetic drift alone is slightly higher than when it is jointly estimated with migration rate (512 vs 287), and so is slightly overestimated. However, both estimates are within the confidence intervals and thus are in the same range. Furthermore, because of the low genetic differentiation between our target and the source populations, the most relevant scale for our $N_{\text {est }}$ is probably the metapopulation scale rather than the discrete population (Fraser et al., 2007).

\section{Factors influencing $N_{\mathrm{e}}$}

Several factors influence $N_{\mathrm{e}}$ and thus the $N_{\mathrm{e}} / N$ ratio. These include unequal sex ratio, fluctuations in population size, inbreeding, overlapping generations and variance in reproductive success (Caballero, 1994; Frankham et al., 2002; Hedrick, 2005). Sex specific fisheries can play a role in some species and catch records have occasionally reported female-sex bias in $R$. clavata due to the earlier inshore migration of females to the spawning grounds (Ryland and Ajayi, 1984). Likewise, multiple paternity and polyandry (Chevolot et al., 2007) could, in principle, affect sex ratios. In the case of $R$. clavata, however, bias in sex ratio alone is extremely improbable to explain the low $N_{\mathrm{e}} / N$ ratio as it will require a sex ratio of approximately $1.5 \times 10^{-5}$ of one sex, based on the formula $N_{\mathrm{e}}=4 N_{e f} \times N_{e m} /\left(N_{e m}+N_{e f}\right)$ (with $N_{e f}$ the effective number of females and $N_{e m}$, the effective number of males; Wright, 1931). The influence of population size fluctuations on the $N_{\mathrm{e}} / N$ ratio is more difficult to assess because there are no long-term reports on fishing effort in relation to population size in $R$. clavata. However, in the timeframe of this study (1965-2004, that is, four generations), fluctuations in population size alone would be unlikely to have a large effect on $N_{\mathrm{e}}$. Furthermore, the long lifespan, which includes overlapping generations would tend to buffer fluctuations in population size (Jorde and Ryman, 1995; Waite and Parker, 1996). Inbreeding is also unlikely to explain the low $N_{\mathrm{e}} / N$ ratio as the population would have to be almost fully inbred in order to explain the ratio based on $N_{\mathrm{e}}=N /(1+F)$ (with $N$ the census population size and $F$ the inbreeding coefficient; Wright, 1931); and no high $f$ was found in any of the locations studied. Finally, the variance in reproductive success is estimated between 2350 and 80000 individuals based on $N_{\mathrm{e}}=(4 N-2) /\left(V_{\mathrm{k}}+2\right)$ (with $N$ the census population size and $V_{\mathrm{k}}$ the variance in reproductive success; Wright, 1938). This kind of variance seems high for a species with low fecundity and high juvenile survival. In comparison with marine species expected to have a high variance in reproductive success (high fecundity and low juvenile survival), the variance is between 57000 and 1000000 for the North Sea plaice (Pleuronectes platessa), between 18000 and 165000 for the New Zealand red snapper (Pagrus auratus) (Hauser et al., 2002), between 30000 and 240000 for the North Sea cod 
(Gadus morhua) (Hutchinson et al., 2003) and 4500 for the red drum (S. ocellatus; Turner et al., 2002). The estimated variance in reproductive success for thornback ray is, therefore, in the same range as these species. Although, complex courtship behaviours have been observed in some batoids (Yano et al., 1999; Chapman et al., 2003), which could lead to male variance in reproductive success, to have a variance in $R$. clavata in about the same range as the North Sea plaice, cod, New Zealand red snapper and the red drum is improbable.

Thus, all of these parameters taken individually do not explain the low $N_{\mathrm{e}} / N$ ratio. As the effective population size is a summarized parameter of many demographic parameters (Caballero, 1994), the synergistic effect of these factors may have reduced the $N_{\mathrm{e}}$ over $N$, as each one affects the other. In addition to all of these parameters, the effect of gene flow on our $N_{\text {est }}$ may further reduce the estimated $N_{\mathrm{e}} / N$ ratio.

\section{Comparison with other marine species}

For most marine species, the estimated $N_{\mathrm{e}} / N$ ratio is between three to five orders of magnitude smaller than the census population size (Hauser et al., 2002; Planes and Lenfant, 2002; Turner et al., 2002; Hutchinson et al., 2003; Hoarau et al., 2005; Gomez-Uchida and Banks, 2006; Poulsen et al., 2006; Laurent and Planes, 2007; Ovenden et al., 2007). All these species are highly fecund species with a typical type III survival curve (that is, high fecundity and high juvenile mortality). In this case, variance in reproductive success is thought to be the primary factor reducing $N_{\mathrm{e}}$ (Hedrick, 2005) due to sweepstake recruitment (Hedgecock, 1994). In this model, young-of-the-year may come from a very small number of successful breeders as a consequence of matched breeding time and local oceanographic conditions. Surprisingly, the estimated $N_{\mathrm{e}} / N$ ratio for $R$. clavata (with a Type II survivorship) is the same order of magnitude. Although caution has to be taken with our estimates, this may suggest that biological characteristics, such as fecundity, mortality rate through cohorts and age of maturity, may not be the best predictors of $N_{\mathrm{e}}$.

\section{Genetic diversity}

The finding of no apparent loss in genetic diversity in $R$. clavata is a good sign, although this estimate spans only the past 40 years and does not predate exploitation by major fisheries. In the absence of samples predating the 1960s, we cannot exclude the possibility that some genetic diversity has, in fact, been lost. The estimated migration rate is similar to that found in Chevolot et al. (2006). Coupled with weak genetic differentiation these results suggest that the Irish Sea population exchanges alleles with more distant populations. Therefore, genetic diversity could have been maintained, at least quantitatively, through gene flow during this past 40 years. Likewise, no loss of genetic diversity was found in the Baltic and Moray Firth cod populations (Poulsen et al., 2006). However, Hutchinson et al. (2003) found a loss of genetic diversity in the North Sea cod between 1954 and 1970 and a subsequent recovery of the level of genetic diversity between 1970 and 1988, thanks to gene flow from neighbourhood populations.

Given the estimated population size of mature $R$. clavata in the Irish Sea and Bristol Channel-within the broad range of between 500000 and 3000000 individuals-long-term monitoring of the abundance and genetic diversity of $R$. clavata in the Irish Sea is certainly warranted. Raja clavata has undergone a more severe decline in the North Sea, though it is uncertain if there has been a decrease in genetic diversity as historical samples are not available for this area. This and earlier studies (for example, Hauser et al., 2002; Hutchinson et al., 2003) highlight the usefulness of properly archived samples for examining temporal trends in the genetic diversity of exploited fish species.

\section{Acknowledgements}

We are thankful to Gary Burt (Cefas) for his help in sampling archived vertebrae, Laura Moria for her assistance with laboratory work and Galice Hoarau for commenting on the article. This research was supported by NWO-PRIORITEIT programme SUSUSE, Project Nr. 885-10-311.

\section{References}

Arnaud-Haond S, Belkhir K (2007). Genclone: a computer program to analyse genotypic data, test for clonality and describe spatial clonal organization. Mol Ecol Notes 7: 15-17.

Belkhir K, Borsa P, Chikhi L, Raufaste N, Bonhomme F (2004). Genetix 4.05. logiciel sous windows TM pour la génétique des populations. Laboratoire Génome, Populations, Interactions, CNRS UMR 5000, Université de Montpellier II: Montpellier, France.

Brander K (1981). Disappearance of common skate Raia batis from Irish Sea. Nature 290: 48-49.

Caballero A (1994). Developments in the prediction of effective population-size. Heredity 73: 657-679.

Chapman DD, Corcoran MJ, Harvey GM, Malan S, Shivji MS (2003). Mating behavior of southern stingrays, Dasyatis americana (Dasyatidae). Environ Biol Fishes 68: 241-245.

Chevolot M, Ellis JR, Hoarau G, Rijnsdorp AD, Stam WT, Olsen JL (2006). Population structure of the thornback ray (Raja clavata L.) in British waters. I Sea Res 56: 305-316.

Chevolot M, Ellis JR, Rijnsdorp AD, Stam WT, Olsen JL (2007). Multiple paternity analysis in the thornback ray, Raja clavata L. I Hered 98: 712-715.

Chevolot M, Reusch TBH, Boele-Bos S, Stam WT, Olsen JL (2005). Characterization and isolation of DNA microsatellite primers in Raja clavata L. (thornback ray, Rajidae). Mol Ecol Notes 5: 427-429.

Dulvy NK, Metcalfe JD, Glanville J, Pawson MG, Reynolds JD (2000). Fishery stability, local extinctions, and shifts in community structure in Skates. Conserv Biol 14: 283-293.

Ellis JR, Dulvy NK, Jennings S, Parker-Humphreys M, Rogers SI (2005). Assessing the status of demersal elasmobranchs in UK waters: a review. J Mar Biolog Assoc UK 85: 1025-1047.

Ellis JR, Shackley SE (1995). Observations on egg-laying in the thornback ray. I Fish Biol 46: 903-904.

Elphinstone MS, Hinten GN, Anderson MJ, Nock CJ (2003). An inexpensive and high-throughput procedure to extract and purify total genomic DNA for population studies. Mol Ecol Notes 3: 317-320.

Frankham R (1995). Effective population-size adult-population size ratios in wildlife-a review. Genet Res 66: 95-107.

Frankham R, Ballou J, Briscoe D (2002). Introduction to Conservation Genetics, 4th edn. University Press: Cambridge.

Franklin I, Frankham R (1998). How large must populations be to retain evolutionary potential. Anim Conserv 1: 69-71.

Fraser DJ, Hansen MM, Østergaard S, Tessier N, Legault M, Bernatchez L (2007). Comparative estimation of effective 
population sizes and temporal gene flow in two contrasting population systems. Mol Ecol 16: 3866-3889.

Gomez-Uchida D, Banks MA (2006). Estimation of effective population size for the long lived darkblotched rockfish Sebastes crameri. J Hered 97: 603-606.

Hauser L, Adcock GJ, Smith PJ, Ramirez JH, Carvalho GR (2002). Loss of microsatellite diversity and low effective population size in an overexploited population of $\mathrm{New}$ Zealand snapper (Pagrus auratus). Proc Natl Acad Sci USA 99: 11742-11747.

Hedgecock D (1994). Does variance in reproductive success limit effective population sizes of marine organisms? In: Beaumont AR (ed). Genetics and Evolution of Aquatic Organisms. Chapman and Hall: London, pp 122-134.

Hedrick PW (2005). Large variance in reproductive success and the $N_{\mathrm{e}} / N$ ratio. Evolution 59: 1596-1599.

Heessen HJLE (2004). Development of Elasmobranchs Assessment, DELASS DG Fish study contract 99/055. Final report. 605 p.

Heist EJ (1999). A review of population genetics in sharks. Am Fish Soc Symp 23: 161-168.

Hoarau G, Boon E, Jongma DN, Ferber S, Palsson J, Van der Veer HW et al. (2005). Low effective population size and inbreeding in Plaice (Pleuronectes platessa): an abundant but overexploited flatfish. Proc $R$ Soc Lond B 272: 497-503.

Holden MJ (1975). Fecundity of Raja clavata in British waters. J Cons Int Exp Mer 36: 110-118.

Hunter E, Buckley AA, Stewart C, Metcalfe JD (2005). Migratory behavior of the thornback ray, Raja clavata in the Southern North Sea. J Mar Biolog Assoc UK 85: 1095-1105.

Hutchinson WF, Carvalho GR, Rogers SI (1999). A nondestructive technique for the recovery of DNA from dried fish otoliths for subsequent molecular genetic analysis. Mol Ecol 8: 893-894.

Hutchinson WF, Van Oosterhout C, Rogers SI, Carvalho GR (2003). Temporal analysis of archived samples indicates marked genetic changes in declining North Sea cod (Gadus morhua). Proc $R$ Soc Lond B 270: 2125-2132.

ICES (2006). Report of the ICES advisory committee on fishery management. Advisory Committee on the Marine Environment and Advisory Committee on Ecosystems ICES Advice. Books $1-10.6,310 \mathrm{pp}$.

ICES (2007). Report on the Working Group on Elasmobranch Fishes (WGEF) Galway, Ireland, ICES CM 2007/ACFM: 27. 18 p.

Jorde PE, Ryman N (1995). Temporal allele frequency change and estimation of effective size in populations with overlapping generations. Genetics 139: 1077-1090.

Lande R (1995). Mutation and conservation. Conserv Biol 9: 782-791.

Laurent V, Planes S (2007). Effective population size estimation on Sardina pilchardus in the Bay of Biscay using a temporal genetic approach. Biol J Linn Soc 90: 591-602.

Maxwell D, Jennings S (2005). Power of monitoring programs to detect decline and recovery of rare and vulnerable fish. J Appl Ecol 42: 25-37.

Nei M (1978). Estimation of average heterozygosity and genetic distance from a small number of individuals. Genetics 89: 583-590.

Nottage AS, Perkins EJ (1983). Growth and maturation of roker Raja clavata L. in the Solway Firth. J Fish Biol 23: 43-48.

Ovenden JR, Peel D, Street R, Courtney AJ, Hoyle SD, Peel SL et al. (2007). The genetic effective and adult census size of an Australian population of tiger prawns (Penaeus esculentus). Mol Ecol 16: 127-138.
Pawson MG, Nichols V (1994). Recapture patterns of rays tagged in the Bristol Channel and Irish sea. In: Fowler SL, Earll RC (eds). Tag and Release Schemes and Shark and Ray Management Plans Proceedings of the Second European Shark and Ray Workshop, pp 10-13.

Planes S, Lenfant P (2002). Temporal change in the genetic structure between and within cohorts of a marine fish, Diplodus sargus, induced by a large variance in individual reproductive success. Mol Ecol 11: 1515-1524.

Poulsen NA, Nielsen EE, Schierup MH, Loeschcke V, Gronkjaer $P$ (2006). Long-term stability and effective population size in North Sea and Baltic Sea cod (Gadus morhua). Mol Ecol 15: 321-331.

Rice WR (1989). Analyzing tables of statistical tests. Evolution 43: 223-225

Rogers SI, Ellis JR (2000). Changes in the demersal fish assemblages of British coastal waters during the 20th century. ICES J Mar Sci 57: 866-881.

Ryland JS, Ajayi TO (1984). Growth and population-dynamics of 3 Raja Species (Batoidei) in Carmarthen Bay, British-Isles. I Cons Int Explor Mer 41: 111-120.

Turner TF, Wares JP, Gold JR (2002). Genetic effective size is three orders of magnitude smaller than adult census size in an abundant, estuarine-dependent marine fish (Sciaenops ocellatus). Genetics 162: 1329-1339.

Van Oosterhout C, Hutchinson WF, Wills DPM, Shipley P (2004). MICRO-CHECKER: software for identifying and correcting genotyping errors in microsatellite data. Mol Ecol Notes 4: 535-538.

Waite TA, Parker PG (1996). Dimensionless life histories and effective population size. Conserv Biol 10: 1456-1462.

Walker PA, Heessen HJL (1996). Long-term changes in ray populations in the North Sea. ICES J Mar Sci 53: 1085-1093.

Walker PA, Howlett G, Millner R (1997). Distribution, movement and stock structure of three ray species in the North Sea and eastern English Channel. ICES J Mar Sci 54: 797-808.

Wang JL (2005). Estimation of effective population sizes from data on genetic markers. Philos Trans $R$ Soc Lond $B$ 360: 1395-1409.

Wang JL, Whitlock MC (2003). Estimating effective population size and migration rates from genetic samples over space and time. Genetics 163: 429-446.

Waples RS (1989). A generalized approach for estimating effective population size from temporal changes in allele frequency. Genetics 121: 379-391.

Waples RS, Yokota M (2007). Temporal estimates of effective population size in species with overlapping generations. Genetics 175: 219-233.

Weir BS, Cockerham CC (1984). Estimating F-statistics for the analysis of population structure. Evolution 38: 1358-1370.

Wilcoxon F (1945). Individual comparisons by ranking methods. Biometrics 1: 80-83.

Wright S (1931). Evolution in Mendelian populations. Genetics 16: $97-159$

Wright S (1938). Size of population and breeding structure in relation to evolution. Science 87: 430-431.

Yano K, Sato F, Takahashi T (1999). Observations of the mating behavior of the manta ray, Manta birostris, at the Ogasawara Islands, Japan. Ichthyol Res 46: 289-296. 